\section{Evolution of differentiated thyroid cancer during pregnancy in a community University Hospital in Buenos Aires, Argentina}

\author{
Evolução do câncer diferenciado de tiroide durante a gestação \\ em um Hospital Universitário de Buenos Aires, Argentina
}

Carmen Amalia Cabezón', Laura Carolina Carrizo', Pablo René Costanzo ${ }^{1}$

\begin{abstract}
Objective: To analyze the presentation, follow-up and evolution of differentiated thyroid cancer (DTC) detected during pregnancy. Subjects and methods: Twenty nine women with DTC detected during pregnancy were analyzed. Group I $(n=13)$ was seen during pregnancy and DTC was diagnosed during gestation; detection of the nodule occurred during pregnancy (first trimester). Group II $(n=16)$ was seen after delivery; detection of the nodule occurred during pregnancy (second or third trimester). Complete thyroidectomy, ablative dose of radioactive iodine, and treatment with levothyroxine were performed. Follow-up: neck ultrasound;TSH, freeT4, thyroglobulin, and anti-thyroglobulin antibodies with and without treatment with levothyroxine; and ${ }^{131}$ | whole body scans. Histological diagnosis, lymph node metastases, tumor size and stage, complications from pregnancy, and DTC evolution were evaluated. Results: $100 \%$ of the patients had papillary thyroid carcinoma. Lymph node metastases were detected in $13(44.8 \%)$, and invasion of adjacent extrathyroid tissue in 2 patients. Tumor size was larger in Group Il: $22.1 \pm 10.9$ versus $13.9 \pm 3.5 \mathrm{~mm} ; \mathrm{p}=0.03$. No differences were found in the tumor stages between groups. All patients had full-term pregnancies and healthy newborns. Follow-up: $5.7 \pm 4.3$ years; one patient had persistent disease. Conclusions: DTC detected during pregnancy had a favorable evolution. Surgery may be postponed to the post-delivery period, unless there are risk factors that justify it during pregnancy. Arq Bras Endocrinol Metab. 2013;57(4):307-11
\end{abstract}

\section{Keywords}

Pregnancy; papillary thyroid carcinoma; thyroid nodule

\section{RESUMO}

Objetivo: Analisar a apresentação, o seguimento e a evolução do câncer diferenciado da tiroide (CDT) durante a gestação. Sujeitos e métodos: Vinte e nove mulheres com CDT detectado durante a gestação foram analisadas. 0 Grupo I $(n=13)$ foi atendido durante a gestação e o CDT foi diagnosticado durante a gravidez; a detecção do nódulo aconteceu durante a gestação (primeiro trimestre). O Grupo II ( $n=16)$ foi atendido depois do parto; a detecção do nódulo aconteceu durante a gestação (segundo ou terceiro trimestre). Foram feitos a tiroidectomia, dose de iodo radioativo e tratamento com levotiroxina. Acompanhamento: ultrassom de pescoço; TSH,T4 livre, tiroglobulina, e anticorpos antitiroglobulina com ou sem tratamento com levotiroxina e imagens de corpo inteiro com ${ }^{131}$ I. Foram analisados o diagnóstico histológico, as metástases em linfonodos, estágio e tamanho do tumor e complicações da gestação e a evolução do CDT. Resultados: Cem por cento das pacientes apresentaram carcinoma papilar da tiroide. Foram detectadas metástases em linfonodos em 13 (44,8\%) pacientes e invasão de tecidos extratiroidianos adjacentes em duas pacientes. $O$ tumor foi maior no Grupo II: $22,1 \pm 10,9$ versus $13,9 \pm 3,5 \mathrm{~mm} ; \mathrm{p}=0,03$. Não foram observadas diferenças nos estágios dos tumores entre os grupos. Não houve partos prematuros e todos os recém-nascidos estavam saudáveis. Acompanhamento: $5,7 \pm 4,3$ anos; uma paciente apresentou doença persistente. Conclusões: O CDT detectado durante a gestação tem evolução favorável. A cirurgia pode ser adiada até o momento pós-parto, a não ser que haja fatores de risco que justifiquem a intervenção durante a gestação. Arq Bras Endocrinol Metab. 2013;57(4):307-11
${ }^{1}$ Endocrinology, Metabolism and Nuclear Medicine Service, Hospital Italiano de Buenos Aires, Argentina

Correspondence to: Costanzo Pablo René Endocrinology, Metabolism and Nuclear Medicine Service, Hospital Italiano de Buenos Aires Gascón, 450

$\mathrm{C} 1181 \mathrm{ACH}$, Buenos Aires, Argentina pablo.costanzo@hospitalitaliano.org.ar

Received on Oct/25/2012 Accepted on Dec/7/2012 


\section{INTRODUCTION}

$\mathrm{P}$ revalence of thyroid nodules is greater in women compared with men, and it is more evident in iodine-deficient areas $(1,2)$. This prevalence increases by age and parity (3).

Pregnancy is a stimulation factor for the development of thyroid neoplasms, mainly in patients with underlying thyroid pathology or genetic predisposition, or in the presence of environmental factors, to which are added pregnancy-related changes in immunological tolerance. Normal physiological changes in pregnancy include increase in maternal thyroid volume, including increased size of thyroid nodules (4). Various authors have reported higher frequency of benign and malignant neoplasms in thyroid nodules detected during pregnancy, with figures as high as $80 \%$ for all neoplasms, 37 to $63 \%$ for benign nodules, and 28.5 to $43 \%$ for differentiated thyroid cancer (DTC) (5-7).

DTC cases detected during pregnancy generally correspond to papillary carcinomas, and usually have favorable evolution.

The aim of this study was to analyze the presentation, follow-up and evolution of DTC detected during pregnancy in 29 women who were seen at the Endocrinology Service in the Hospital Italiano of Buenos Aires, a community university hospital, between 1992-2010, in an iodine-sufficient area.

\section{SUBJECTS AND METHODS}

The medical histories of 29 patients with DTC diagnosis confirmed histologically were analyzed retrospectively. In all cases, the reason for the appointment was the detection of a thyroid nodule during pregnancy.

A physical exam and thyroid ultrasound, along with routine and hormone laboratory tests (including thyrotropin [TSH], free thyroxine [free T4], antithyroperoxidase antibodies [ATPO] and fine needle aspiration biopsy $[\mathrm{FNAB}]$ ) were performed on all patients.

The population was divided into two groups according to when the patient came for the appointment:

- Group I $(\mathrm{n}=13)$, patients were seen during pregnancy and DTC was diagnosed during gestation. Detection of the nodule occurred during the first trimester of pregnancy.

- Group II $(\mathrm{n}=16)$, patients were seen after delivery. Detection of the nodule occurred during pregnancy (second or third trimester) in all cases.
All patients underwent surgery and total thyroidectomy, ablative dose of radioactive iodine, and inhibitory TSH treatment with levothyroxine, according to protocols. Follow-up included: physical examination, neck ultrasounds, measurement of TSH, free T4, thyroglobulin, anti-thyroglobulin antibodies by an ultrasensitive method with levothyroxine treatment and under stimulation with endogenous TSH by levothyroxine withdrawal. ${ }^{131} \mathrm{I}$ scans were carried out a year after the ablative dose in all patients, and then only in patients with persistent disease according to protocols adjusted to risk factors. All ${ }^{131}$ I scans were performed under stimulation with endogenous TSH by levothyroxine withdrawal. Except for the period prior to ablation with radioactive iodine or ${ }^{131} \mathrm{I}$ control scans, patients received levothyroxine with a TSH-inhibiting criterion.

For DTC staging, University of Chicago clinical staging classification was used (8): Stage I (intrathyroid nodule); Stage II (lymph node metastases); Stage III (local extension), and Stage IV (distant metastases).

At the end of follow-up, patients were considered free of disease if there was no clinical evidence of disease, including absence of adenopathies in the neck ultrasound, negative ${ }^{131}$ I scans and thyroglobulin undetected under TSH stimulus by levothyroxine withdrawal.

\section{Statistical analysis}

Data was analyzed with Instat Statistical Software (GraphPad Software, 3.05 version, San Diego, USA). Differences in the characteristics of Group I and Group II patients were compared with a two-sample $t$ test for continuous variables; categorical variables were compared using Chi square. To establish correlations, linear regression was used. Data are presented as a means \pm SD. All $p$ values are two-sided, and values below 0.05 were considered as statistically significant.

\section{RESULTS}

Average age of the patients was $32.5 \pm 4.7$ years. Patients came from iodine-sufficient areas without history of previous radiation therapy in the neck.

Five of the 29 patients (17.2\%) had Hashimoto thyroiditis with adequately substituted hypothyroidism prior to DTC detection.

FNAB was compatible with papillary carcinoma in 26 patients, and with follicular neoplasm in 3 patients. 
Total thyroidectomy was performed within $15.9 \pm$ 12.0 months of detection. In 5 out of 13 Group I patients, it was performed in the second trimester of pregnancy, in the rest of Group I patients, it was carried out 1-6 months post-delivery, and it was performed within 3-36 months after delivery in all Group II patients.

All patients had histological diagnosis of papillary thyroid carcinoma (24 classical papillary carcinoma cases, 2 oncocytic cases, and 3 tall cell cases). In 7 patients (24\%), a histological pattern compatible with Hashimoto thyroiditis was detected.

Lymph node metastases were detected in 13 patients (44.8\%); 6 (46.1\%) from Group I and 8 (50\%) from Group II. Invasion of adjacent extrathyroid tissue was observed in 2 patients, one from each group.

When comparing both groups, there were no significant differences in age and follow-up time. Time elapsed between detection of the nodule and the appointment, and between cytological diagnosis and surgery was less in Group I patients than in Group II (Table 1).

In patients that were seen later (Group II), larger tumor size was observed (Group I: $13.9 \pm 3.5$ versus Group II: $22.1 \pm 10.9 \mathrm{~mm} ; \mathrm{p}=0.03)$. There was a positive correlation between time of nodule detection and tumor size (r: 0.82, $\mathrm{p}<0.0001)$ (Figure 1$)$.

No differences in tumor stages were detected in either group (Figure 2).

All patients had full-term pregnancies and healthy newborns. Deliveries were vaginal in 100\% of Group II patients, whereas $50 \%$ of Group I patients underwent cesarean sections. All patients received post-surgical ${ }^{131}$ I ablative doses at intervals away from delivery and breastfeeding. One patient had positive anti-thyroglobulin antibodies before ablative dose, and became negative later on. Follow-up time was $5.78 \pm 4.32$ years (median 9 years; range $1-20$ years). In the evaluation at the end of the follow-up, just one patient from Group II had persistent disease.

Table 1. Comparison of age, time of detection, diagnosis, and follow-up between women with DTC detected during pregnancy. Group I ( $\mathrm{n}=13$ ) seen during pregnancy and DTC diagnosed during gestation, and group $\|(n=16)$ seen after delivery

\begin{tabular}{|c|c|c|c|}
\hline & $\begin{array}{l}\text { Group I } \\
n=13\end{array}$ & $\begin{array}{c}\text { Group II } \\
n=16\end{array}$ & $\mathbf{p}$ \\
\hline Time of appointment & During pregnancy & Post-delivery & \\
\hline Age (years) & $33.4 \pm 4.6$ & $31.8 \pm 4.7$ & 0.48 \\
\hline Time between thyroid nodule detection and appointment (months) & $3.0 \pm 3.2$ & $16.6 \pm 9.4$ & 0.0005 \\
\hline Time between DTC diagnosis and surgery (months) & $6.5 \pm 3.6$ & $19.7 \pm 9.6$ & $<0.0001$ \\
\hline Follow-up time (years) & $6.1 \pm 4.5$ & $5.5 \pm 4.2$ & 0.69 \\
\hline
\end{tabular}

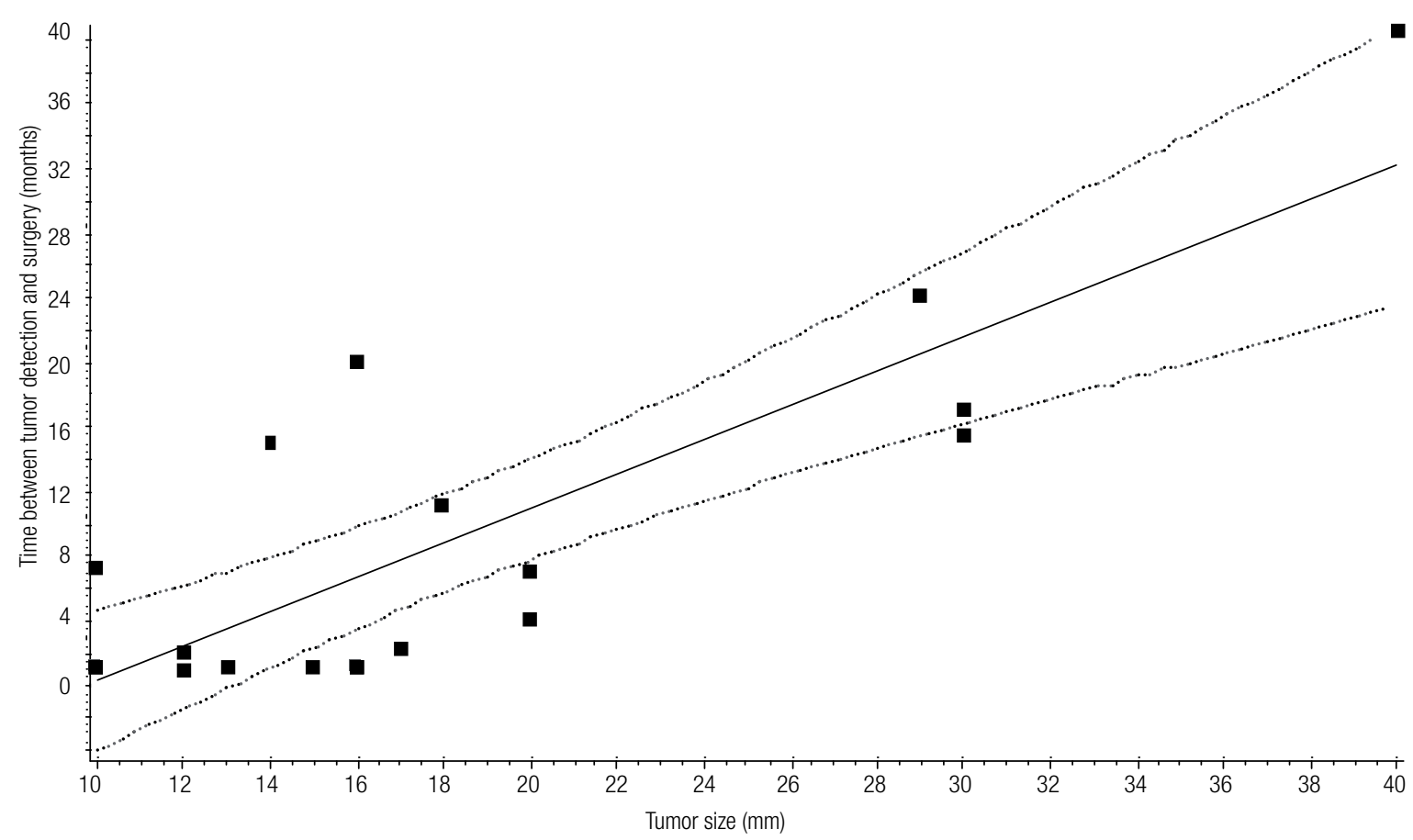

Figure 1. Correlation between time of detection and tumor size. 


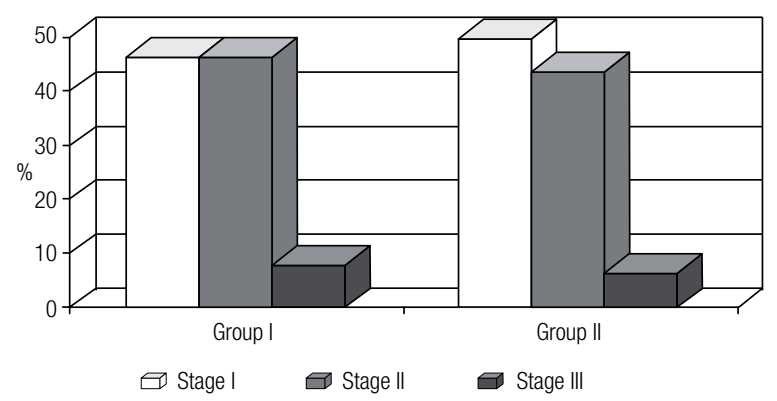

Figure 2. Comparison of tumor stages between women with DTC detected during pregnancy. Group I $(n=13)$ seen during pregnancy and DTC diagnosed during gestation, and group $\|(n=16)$ seen after delivery.

\section{DISCUSSION}

DTC is a frequently diagnosed entity, usually present in women at reproductive age. California records have shown a prevalence of thyroid cancer detected during pregnancy in 14 out of every 100,000 live newborns, versus 4 out of every 100,000 in the general population, and it is the second most frequent cancer detected in pregnant women after breast cancer (9). Prevalence of DTC in pregnant women is estimated at $1 / 1,000$ cases, mostly papillary carcinomas with favorable evolution (10). Thyroid cancer is likely to be asymptomatic and diagnosed by a palpable nodule found in the prenatal examination. The approach to diagnosis in a pregnant woman with a palpable thyroid nodule is similar to that in the non-pregnant woman (11).

The presence of cancer in thyroid nodules among pregnant women is more than 5 to $10 \%$ of the rate observed for the general population $(12,13)$. In a study that included 61 pregnant patients with thyroid nodules, DTC was detected and histologically confirmed in 30 patients $(43 \%)(10)$. In another study that included 21 patients in the same situation, DTC was detected in 8 patients $(28.5 \%)(6)$.

To our knowledge, this is the Argentinian case study reported the highest number of patients with DTC detected during pregnancy. The series with the highest number of patients having these characteristics belongs to Moosa and Mazzaferri, with 61 patients (14); Rosen and cols, with 30 patients (10); Nam and cols., with 22 patients (15); and Herzon and cols., with 21 patients (16).

All patients included in this study had papillary carcinoma appearing as a thyroid nodule during pregnancy. From a total of 29 patients, 13 were seen during pregnancy (Group I), and the rest, 3 to 36 months post-delivery (Group II). Delays in the appointment of the lat- ter patients may be attributed to the fact that the thyroid nodule was detected close to the delivery date, so its study and treatment was put off to the post-delivery period.

In patients that were seen later (after delivery), a larger tumor size was observed. This finding was probably due to a longer persistence of disease and greater stimulation of growth during pregnancy. There was a positive correlation between the time of nodule detection and tumor size.

Evolution of DTC was favorable in both groups at the end of follow-up. Only one patient from Group II had persistent disease.

Most reported series indicate no differences in the evolution of DTC detected during pregnancy and DTC occurrence outside pregnancy. Yasmeen and cols. (17) carried out a comparative analysis of data obtained from the California Cancer Registry of 595 patients with DTC detected during pregnancy or up to 12 months after delivery, and 2,270 non-pregnant patients with DTC, grouped by age and tumor stage; no differences in evolution were observed. Other studies found no differences in the evolution of DTC in relation to pregnancy (14). On the other hand, Vannucchi and cols. (18) observed greater persistence of the disease in their population of 15 pregnant patients with DTC in comparison with 61 non-pregnant patients with DTC. This difference was attributed by the authors to the presence of alpha estrogen receptors in the carcinoma of pregnant women at a higher rate than in non-pregnant patients, hypothesizing that this might be a stimulus for tumor growth.

As far as the opportunities for surgery are concerned, based on the evidence in the majority of the published studies, in which evolution was similar in DTC patients operated during pregnancy or after delivery, several authors (19-21) and the international guidelines of the American Thyroid Association (ATA) (22) propose surgery in the post-delivery period unless there are negative evolving risk factors, such as histological findings of differentiation, lymph node involvement, or rapid tumor growth. If surgery is decided upon, it may be performed in the second trimester, preferably in week 22. If diagnosis occurs later, surgery is indicated after delivery $(20,23,24)$.

In this line of conduct, there is a growing prevalence towards a non-interventionist approach in pregnant patients. Given the evidence of good evolution of DTC detected during pregnancy and the fact that, even with DTC diagnosis, few pregnant patients will 
undergo surgery during gestation, it is advisable to indicate FNAB to pregnant patients seen about thyroid nodules, depending on risk factors. Among these, noteworthy are ultrasound findings of thyroid nodule malignancy $(21,22,25)$.

In our population, 4 of the 5 patients underwent surgery during pregnancy, as a result of clinically evidenced lymph node involvement. Even though delays in surgical treatment among patients who were seen after delivery are associated with a larger tumor size, there were no differences in the stage and evolution, compared with patients who were seen during pregnancy.

All patients had full-term pregnancies with live newborns. Noteworthy is the fact that patients in whom cancer was detected during pregnancy had a higher rate of cesarean sections; no clear reasons were established in any of the cases. This may indicate anxiety aroused in patients, their families, and the medical team as a result of a cancer diagnosis during pregnancy. As several authors have pointed out, the occurrence of cancer is a complex situation for the mother, the fetus, and the attending physician. There are inevitable conflicts between the optimum therapy for the mother and the welfare of the fetus $(21,26)$.

DTC detected during pregnancy has characteristics and evolution similar to those of the general population, with favorable evolution, as in young patients. There should be a careful balance to avoid interventions that might impact negatively on the mother, the health of the fetus, and pregnancy progress. Surgery may be postponed to the post-delivery period, unless there are risk factors justifying it during pregnancy.

In our experience, evolution of CDT detected during pregnancy is favorable and does not vary according to the time of appointment being during pregnancy or after delivery.

Disclosure: no potential conflict of interest relevant to this article was reported.

\section{REFERENCES}

1. Kung AW, Chau MT, Lao TT, Tam SC, Low LC. The effect of pregnancy on thyroid nodule formation. J Clin Endocrinol Metab. 2002;87(3):1010-4.

2. Knudsen N, Laurberg P, Perrild H, Bülow I, Ovensen L, Jorgensen T. Risk factors for goiter and thyroid nodules. Thyroid. 2002;12(10):879-88.

3. Struve CW, Haupt S, Ohlen S. Influence of frequency of previous pregnancies on the prevalence of thyroid nodules in women without clinical evidence of thyroid disease. Thyroid. 1993;3(1):7-9.

4. Yazbeck CF, Sullivan SD. Thyroid disorders during pregnancy. Med Clin North Am. 2012;96(2):235-56.
5. Rosen IB, Walfish PG. Pregnancy as a predisposing factor in thyroid neoplasia. Arch Surg. 1986;121(11):1287-90.

6. Tan GH, Gharib H, Goellner JR, van Heerden JA, Bahn RS. Management of thyhroid nodules in pregnancy. Arch Intern Med. 1996;156(20):2317-20.

7. Marley EF, Oertel YC. Fine-needle aspiration of thyroid lesions in 57 pregnant and postpartum women. Diagn Cytopathol. 1997;16(2):122-5.

8. DeGroot LJ, Kaplan EL, McCormick M, Straus FH. Natural history, treatment and course of papillary thyroid carcinoma. J Clin Endocrinol Metab. 1990;71(2):414-24.

9. Smith LH, Danielsen B, Allen ME, Cress R. Cancer associated with obstetric delivery: results of linkage with the California cancer registry. Am J Obstet Gynecol. 2003;189(4):1128-35.

10. Rosen IB, Korman M, Walfish PG. Thyroid nodular disease in pregnancy: current diagnosis and management. Clin Obstet Gynecol. 1997;40(1):81-9.

11. Fitzpatrick DL, Russell MA. Diagnosis and management of thyroid disease in pregnancy. Obstet Gynecol Clin North Am. 2010;37(2):173-93.

12. Mazzaferri EL. Management of a solitary thyroid nodule. N Engl J Med. 1993;328(8):553-9.

13. Rojeski MT, Gharib H. Nodular thyroid disease. Evaluation and management. N Engl J Med. 1985;313(7):428-36.

14. Moosa M, Mazzaferri EL. Outcome of differentiated thyroid cancer diagnosed in pregnant women. J Clin Endocrinol Metab. 1997;82(9):2862-6.

15. Nam KH, Yoon JH, Chang HS, Park CS. Optimal timing of surgery in well-differentiated thyroid carcinoma detected during pregnancy. J Surg Oncol. 2005;91(3):199-203.

16. Herzon FS, Morris DM, Segal MN, Rauch G, Parnell T. Coexistent thyroid cancer and pregnancy. Arch Otolaryngol Head Neck Surg. 1994;120(11):1191-3.

17. Yasmeen S, Cress R, Romano PS, Xing G, Berger-Chen S, Danielsen B, et al. Thyroid cancer in pregnancy. Int J Gynaecol Obstet. 2005;91(1):15-20.

18. Vannucchi G, Perrino M, Rossi S, Colombo C, Vicentini L, Dazzi $D$, et al. Clinical and molecular features of differentiated thyroid cancer diagnosed during pregnancy. Eur J Endocrinol. 2010;162(1):145-51.

19. Owen RP, Chou KJ, Silver CE, Beilin Y, Tang JJ, Yanagisawa RT, et al. Thyroid and parathyroid surgery in pregnancy. Eur Arch Otorhinolaryngol. 2010;267(12):1825-35.

20. Rosen IB, Walfisch PG, Nikore V. Pregnancy and surgical thyroid disease. Surgery. 1985;98(6):1135-40.

21. Mazzaferri EL. Approach to the pregnant patient with thyroid cancer. J Clin Endocrinol Metab. 2011;96(2):265-72.

22. Stagnaro-Green A, Abalovich M, Alexander E, Azizi F, Mestman $\mathrm{J}$, Negro R, et al; American Thyroid Association Taskforce on Thyroid Disease During Pregnancy and Pospartum. Guidelines of the American Thyroid Association for the diagnosis and management of thyroid disease during pregnancy and postpartum. Thyroid. 2011;21(10):1081:125.

23. Sam S, Molitch ME. Timing and special concerns regarding endocrine surgery during pregnancy. Endocrinol Metab Clin North Am. 2003;32(2):337-54.

24. Hay ID. Nodular thyroid disease diagnosed during pregnancy: how and when to treat. Thyroid. 1999;9(7):667-70.

25. Papini E, Guglielmi R, Bianchini A, Crescenzi A, Taccogna S, Nardi $F$, et al. Risk of malignancy in nonpalpable thyroid nodules: predictive value of ultrasound and color-Doppler features. J Clin Endocrinol Metab. 2002;87(5):1941-6.

26. Oduncu FS, Kimmig R, Hepp H, Emmerich B. Cancer in pregnancy: maternal-fetal conflict. J Cancer Res Clin Oncol. 2003;129(3):133-46. 